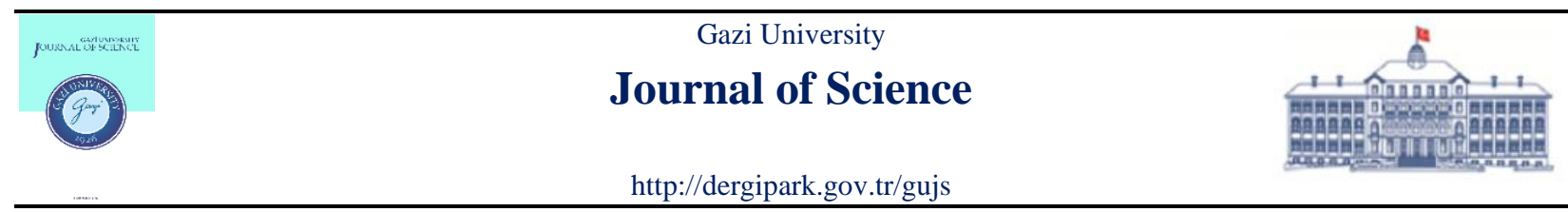

\title{
Green Supplier Selection Based on the Combination of Fuzzy SWARA (SWARA-F) and Fuzzy MARCOS (MARCOS-F) Methods
}

\author{
Aysegul TUS* (i) , Esra AYTAC ADALI (it) \\ Pamukkale University, Business Administration Department, 20070, Denizli, Turkey
}

\author{
Highlights \\ - Proposes MCDM methodology that includes the combination of SWARA-F and MARCOS-F methods. \\ - Implements the novel hybrid MCDM methodology for green supplier selection. \\ - Presents real case study for the solution based on prioritizing and selecting the green suppliers.
}

Article Info

Received: 05 Aug 2021

Accepted: 28 Dec 2021

Keywords

Multi criteria decision making,

SWARA-F

MARCOS-F

Green supplier selection

\begin{abstract}
The green supply chain operations try to minimize environmental impact over the product's lifetime including product recycling or use, reduction of harmful substances, resource saving, green design, etc. Supplier selection is the vital issue in green purchasing. This paper aims to develop applicable and efficient methodology for green supplier selection. The proposed methodology includes the combination of Fuzzy Stepwise Weight Assessment Ratio Analysis (SWARA-F) and Fuzzy Measurement Alternatives and Ranking according to the COmpromise Solution (MARCOS-F) methods. Fuzzy extensions of these methods are preferred because of the complexity of the green supplier selection problem and inclusion of both quantitative and qualitative criteria. Also, these criteria may be uncertain and conflict with each other. It is the first time that SWARA-F is combined with MARCOS-F for the green supplier assessment and selection of the best one among them. The effectiveness of the proposed methodology is demonstrated by solving the real selection problem of a company from textile industry. In the problem both classic and green criteria including main and sub-criteria are considered. SWARA$\mathrm{F}$ is used for weighting the evaluation criteria and the rank of each green supplier alternatives is obtained from incomplete information by assessment score calculated from MARCOS-F. The effectiveness of the combination of two methods is verified by sensitivity and comparative analyses. The proposed methodology provides acceptable and satisfactory results in determining the best green supplier namely improving the environmental and cost efficiency evaluation process.
\end{abstract}

\section{INTRODUCTION}

The supply chain includes operations related with getting materials, producing intermediate and final products and distributing them to customers which provide relationships with suppliers and customers [1]. The management of these -upstream and downstream- relationships is called Supply Chain Management (SCM) [2]. It includes not only flows of money, processes, information and material but also planning of production and distribution scheduling $[3,4]$. The main goal of SCM is adding customer value to the supply chain at less cost [2]. To achieve this goal, matching the right products with the right customers is vital. In the short run, effective SCM provides a reduction in inventory cycle time and an increase in productivity whereas in the long run, it provides an augmentation in the customer satisfaction and market share [5].

Suppliers are main and vital players of SCM. The supplier selection and their performance evaluations are strategic and critical decisions for the companies [6]. There are many scientific approaches in the literature that are suggested to make these decisions effectively. This study focuses on the suppliers selection decision process in which companies identify initial set of supplier alternatives, evaluate them, choose the bests and 
make contract with suppliers. Actually, reduction the alternatives to the final choices is the main aim of this process [7]. While evaluating the suppliers who have potential for fulfilling the companies' needs consistently and at an acceptable cost, multiple factors or criteria (qualitative or quantitative) are examined [5]. When the supplier selection literature has been reviewed, some common criteria such as quality, performance and delivery on time are encountered by the researchers [8]. However due to environmental awareness, environmental protection, governmental legislation and sustainable development issues, companies cannot survive in the global market considering only these criteria [6]. By adding the environmental thinking to the SCM, Green Supply Chain Management (GSCM) has arisen [9]. GSCM is the combination of environmental and SCM operations including material selection, product design, manufacturing, distribution and recycling [10]. Throughout the green supply chain, the green suppliers play a critical role and help the company to produce products with the right quality at a reasonable price as well as totally remove the environmental impact of operations in the supply chain.

As mentioned earlier, supplier selection and also green supplier selection are complex processes that consider multiple factors or criteria. Therefore, it is considered as a Multi Criteria Decision Making (MCDM) problem and solved with different MCDM analyzes. However, fuzzy structure in different parts of life makes such MCDM analyzes even more difficult. Decision makers' preferences and evaluations on a specific subject are often fuzzy and complex. The evaluations or opinions of decision makers cannot be expressed completely. Even the problem may involve uncertain and conflicting factors that cannot be foreseen and controlled [8]. Fuzzy set theory proposed by Zadeh [11] can enable to cope with ambiguity and complexity in the problem. Thanks to fuzzy set theory, precise evaluations are processed with linguistic variables and evaluations. In this study, an evaluation methodology is proposed to judge wide variety of green suppliers for a company which has environmental considerations. The objectives of current study can be summarized as: (i) to determine the selection criteria taken into account in evaluating green suppliers, (ii) to compute the relative importance weights of green supplier selection criteria, (iii) to rank green suppliers and select the best one by using a real case study in Turkey and (iv) to propose a practical and effective fuzzy decision making evaluation methodology to the decision makers for green supplier selection by achieving the first three objectives.

Fuzzy extensions of SWARA and MARCOS shortly named as SWARA-F and MARCOS-F are performed to measure validity of the methodology. In the application part, traditional and green criteria are integrated and weighted by SWARA-F. SWARA-F is one of the subjective weighting methods which is important in terms of reflecting decision makers' professional knowledge and experience. SWARA-F has several advantages when compared to other weighting methods. There is no need for large number of pairwise comparison matrices to determine relationships between criteria [12]. On the other hand, ranking and selection of potential green suppliers are performed with MARCOS-F. MARCOS method proposed by Stević et al. [13] was used to select sustainable suppliers. They also compared this method with other MCDM methods. As a result of the comparison, MARCOS method yielded good results and provided certain advantages over other MCDM methods in terms of processing ideal and anti-ideal solutions. To the best of our knowledge, combining SWARA-F and MARCOS-F is used for the first time in solving green supplier selection problem. To fill the gap in fuzzy MCDM literature, a real case study from Turkey has been presented. In this paper, sensitivity analysis is conducted to reveal the changes in rank order of green supplier alternatives due to variations of decision makers' weights in MARCOS method. Also, a comparative analysis is conducted between the rank orders of green supplier alternatives from MARCOSF, CODAS-F, TOPSIS-F, and EDAS-F methods. A researcher may notice that complex decision making processes can be dealt more smoothly and efficiently by the proposed integrated evaluation methodology. Moreover, sensible and logical solutions for the problems and situations are provided by strengthening with multi-faceted decision analyses. The study also provides extensive literature review of these methods.

The organization of study is as follows. Literature related with green supplier selection criteria and selection methods are reviewed at the second section. In the third section, firstly main concepts of fuzzy set theory and basic fuzzy operations are presented. After that, core methods of this study are explained in detail. In the fourth section, a real case study from textile industry is solved. In the fifth section, sensitivity and comparative analyses are performed. In the sixth section, discussion and managerial implications are conducted. Finally, the conclusion and future research are given. 


\section{LITERATURE REVIEW}

Different evaluation models are proposed for the green supply selection in the literature. These models handle both qualitative and quantitative criteria including traditional and green criteria. The most commonly used traditional criteria are cost, service and product quality, on time delivery, and flexibility [8]. The green criteria are mentioned with different names in different studies. While some authors have taken the green criteria generally, some authors have discussed these criteria in more detail. But in general, green criteria include green production process activities [14]. On the other hand, some researchers have considered only environmental sustainability issues and they have handled only environmental criteria for supplier selection [5]. Table 1 summarizes the results of the literature review in terms of the criteria used for green supply selection.

Table 1. Summary of green supplier selection criteria

\begin{tabular}{|c|c|c|}
\hline Criteria & Authors & Definitions \\
\hline $\begin{array}{l}\text { Service or } \\
\text { Service Level }\end{array}$ & Banaeian et al. [15], Sarwar et al. [16], Sun and Chai [17] & $\begin{array}{l}\text { Performance in terms of reliability, responsiveness, } \\
\text { assurance, warranty, on time delivery, after sale } \\
\text { service, satisfaction }\end{array}$ \\
\hline Cost & $\begin{array}{l}\text { Zafar et al. [5], Galankashi et al. [7], Banaeian et al. [15], Sarwar et al. } \\
\text { [16], Sun and Chai [17], Tuzkaya et al. [18], Gao et al. [19], Xu et al. } \\
\text { [23], Javad et al. [24], Duan et al [27] }\end{array}$ & $\begin{array}{l}\text { Purchasing, production, transportation, inspection, } \\
\text { security, inventory, warranty, environmental costs }\end{array}$ \\
\hline Quality & $\begin{array}{l}\text { Zafar et al. [5], Galankashi et al. [7], Bali et al. [14], Banaeian et al. [15], } \\
\text { Sarwar et al. [16], Sun and Chai [17], Gao et al. [19], Mohammed et al. } \\
\text { [21], Xu et al. [23], Yazdani et al. [26], Duan et al. [27] }\end{array}$ & $\begin{array}{l}\text { Material quality, operation excellence including } \\
\text { percentage of defective products and percentage of } \\
\text { rejected products, quality assurance and quality } \\
\text { related certificates }\end{array}$ \\
\hline Green Product & $\begin{array}{l}\text { Buyukozkan and Cifci [4], Zafar et al. [5], Kannan et al. [6], Galankashi } \\
\text { et al. [7], Bali et al. [14], Sarwar et al. [16], Tuzkaya et al. [18], Gao et al. } \\
\text { [19], Qin et al. [22], Duan et al [27] }\end{array}$ & $\begin{array}{l}\text { Green processes including green packaging, } \\
\text { recycling, remanufacturing, reusing }\end{array}$ \\
\hline Green Design or R\&D & Galankashi et al. [7], Bali et al. [14], Kannan et al. [20], Javad et al. [24] & R\&D activities for green design and green products \\
\hline
\end{tabular}

When the literature has been reviewed for solution methods of green supply selection problems, it is seen that different single and integrated methods have been proposed. These methods are summarized as MCDM methods, weighted linear model approaches, mathematical programming models, clustering methods, models based on human judgment, statistical analysis, and heuristic approaches [8]. In this study, we focused only on studies based on fuzzy set theory and MCDM methods. Table 2 summarizes existing single and integrated fuzzy MCDM methods for such problems.

Table 2. Existing fuzzy MCDM methods for green supplier selection problems

\begin{tabular}{|c|c|c|c|}
\hline & Single methods & Integrated methods & \\
\hline Fuzzy TOPSIS & $\begin{array}{l}\text { Sarwar et al. [16], Mohammed et al. [21], Dogan et } \\
\text { al. [28], Mousakhani et al. [29], } \\
\text { Yucesan et al. [30], Rouvendegh et al. [31] }\end{array}$ & Fuzzy ANP and Fuzzy PROMETHEE & Tuzkaya et al. [18] \\
\hline Fuzzy GRA & Vishnu et al. [32] & Fuzzy AHP and Fuzzy MOLP & Shaw et al. [44] \\
\hline Fuzzy AHP & Zafar et al. [5], Ecer [33] & $\begin{array}{l}\text { Fuzzy ANP, Fuzzy DEMATEL and Fuzzy } \\
\text { TOPSIS }\end{array}$ & Buyukozkan and Cifci [4] \\
\hline Fuzzy ANP & Galankashi et al. [7], Mina et al. [34] & Fuzzy AHP, Fuzzy TOPSIS, Fuzzy MOLP & Kannan et al. [20] \\
\hline $\begin{array}{l}\text { Intuitionistic Fuzzy } \\
\text { ELECTRE }\end{array}$ & Ustunyer et al. [35] & Intuitionistic Fuzzy Set and GRA & Bali et al. [14] \\
\hline Fuzzy DEA & $\mathrm{Yu}$ and $\mathrm{Su}[36]$ & Fuzzy TOPSIS and TODIM & Arshadi Khamseh and Mahmoodi [10] \\
\hline $\begin{array}{l}\text { Fuzzy } \\
\text { MULTIMOORA }\end{array}$ & Sen et al. [37] & Fuzzy AHP and Fuzzy ARAS & Mavi [45] \\
\hline Fuzzy $\mathrm{AD}$ & $\begin{array}{l}\text { Kannan et al. [6], Beng and Badrul [38], Guo et al. } \\
\text { [39] }\end{array}$ & $\begin{array}{l}\text { Interpretive Structural Modeling, Fuzzy } \\
\text { MICMAC, Fuzzy AHP and Fuzzy VIKOR }\end{array}$ & Gavareshki et al. [46] \\
\hline Fuzzy TODIM & Qin et al. [22], Sang and Liu [40] & $\begin{array}{l}\text { Fuzzy TOPSIS, Fuzzy VIKOR and Fuzzy } \\
\text { GRA }\end{array}$ & Banaeian et al. [15] \\
\hline Fuzzy WASPAS & Keshavarz Ghorabaee et al. [41], Mishra et al. [42] & $\begin{array}{l}\text { BWM, Modified fuzzy TOPSIS and Fuzzy } \\
\text { MOLP }\end{array}$ & Lo et al. [47] \\
\hline \multirow[t]{5}{*}{$\begin{array}{l}\text { Intuitionistic Fuzzy } \\
\text { COPRAS }\end{array}$} & \multirow[t]{5}{*}{ Kumari and Mishra [43] } & $\begin{array}{l}\text { Fuzzy AHP, Fuzzy TOPSIS, Fuzzy } \\
\text { WASPAS and Fuzzy MABAC }\end{array}$ & Gupta et al. [48] \\
\hline & & Fuzzy PIPRECIA and Interval Rough SAW & Đalić et al. [49] \\
\hline & & Fuzzy TOPSIS and Fuzzy ELECTRE & Qu et al. [50] \\
\hline & & BWM and fuzzy TOPSIS & Javad et al. [24] \\
\hline & & $\begin{array}{l}\text { Hesitant Fuzzy Linguistic SWARA and } \\
\text { DNMA }\end{array}$ & Liao et al. [51] \\
\hline
\end{tabular}




\section{SWARA-F AND MARCOS-F METHODS FOR GREEN SUPPLIER SELECTION}

\subsection{Fuzzy Set Theory}

Fuzzy set theory was firstly introduced by Zadeh [12]. The main aim of the theory is modelling the uncertainty and vagueness mathematically. Also, it provides methods for analyzing the uncertainty in the structure of most decision problems [5]. A fuzzy set is defined as an extension of a crisp set. $\mu_{\tilde{A}}(\mathrm{x})$ presents membership function of a fuzzy set $\tilde{A}$ and it can take any real number value in the range $[0,1]$. Uncertain information in a problem or uncertain judgments of decision-makers are represented by a fuzzy number. A fuzzy number $\tilde{A}$ can be defined as a convex normalized fuzzy set $\tilde{A}$ belonging to the real line R. It has two features: (1) It exists such that $x_{0} \in R$ with $\mu_{\tilde{A}}\left(x_{0}\right)=1$ and (2) $\mu_{\tilde{A}}(x)$ is piecewise continuous [52].

It is preferred to use triangular fuzzy numbers (TFNs) in this study. TFNs are characterized as a triplet ( $\mathrm{a}_{1}$, $\mathrm{a}_{2}, \mathrm{a}_{3}$ ) and its membership function is described in Equation (1):

$$
\mu_{\tilde{A}}(\mathrm{x})= \begin{cases}0, & \mathrm{x}<\mathrm{a}_{1} \\ \left(\mathrm{x}-\mathrm{a}_{1}\right) /\left(\mathrm{a}_{2}-\mathrm{a}_{1}\right), & \mathrm{a}_{1}<\mathrm{x}<\mathrm{a}_{2} \\ \left(\mathrm{a}_{3}-\mathrm{x}\right) /\left(\mathrm{a}_{3}-\mathrm{a}_{2}\right), & \mathrm{a}_{2}<\mathrm{x}<\mathrm{a}_{3} \\ 0, & \mathrm{x}>\mathrm{a}_{3}\end{cases}
$$

By considering any two positive TFNs, $\tilde{A}=\left(\mathrm{a}_{1}, \mathrm{a}_{2}, \mathrm{a}_{3}\right)$ and $\tilde{B}=\left(\mathrm{b}_{1}, \mathrm{~b}_{2}, \mathrm{~b}_{3}\right)$ and a positive real number $r$, some main algebraic operations of two TFNs are expressed in the following [53]:

$\widetilde{\mathrm{A}}+\widetilde{\mathrm{B}}=\left(\mathrm{a}_{1}+\mathrm{b}_{1}, \mathrm{a}_{2}+\mathrm{b}_{2}, \mathrm{a}_{3}+\mathrm{b}_{3}\right)$

$\widetilde{A}-\widetilde{B}=\left(a_{1}-b_{3}, a_{2}-b_{2}, a_{3}-b_{1}\right)$

$\widetilde{\mathrm{A}} \times \mathrm{r}=\left(\mathrm{a}_{1} \mathrm{r}, \mathrm{a}_{2} \mathrm{r}, \mathrm{a}_{3} \mathrm{r}\right)$

$\widetilde{A} \times \widetilde{B}=\left(a_{1} b_{1}, a_{2} b_{2}, a_{3} b_{3}\right)$

$\widetilde{A} \div \widetilde{B}=\left(a_{1} \div b_{3}, a_{2} \div b_{2}, a_{3} \div b_{1}\right)$.

Defuzzification process is required when a researcher wants to use a crisp number as output from a fuzzy system [54]. In this study, graded mean integration method [55] is adopted in terms of simplicity. This method defuzzifies a TFN $\tilde{A}=\left(\mathrm{a}_{1}, \mathrm{a}_{2}, \mathrm{a}_{3}\right)$ as in Equation (7). $R(\tilde{A})$ is deffuzified value of $\tilde{A}$ [56]

$R(\tilde{A})=\frac{a_{1}+4 a_{2}+a_{3}}{6}$.

\subsection{Determining Selection Criteria and Alternatives}

The companies have realized importance of the supplier selection issue for their operations due to increased environmental awareness and pressures. Green supplier selection process in GSCM requires several decision making steps. After defining company's problem exactly, the next step is determination of green supplier selection criteria by considering needs of a company or structure of a problem. The decision makers, experts or decision committee identify the criteria by reviewing existing literature, considering industry's specifications or examining on-site [39]. Both traditional and green criteria may be considered. After determining the criteria, a set of potential green supplier alternatives that meet these criteria is identified. In order to compare the alternatives with each other, it is necessary to clearly specify their performances under each criterion. The selection problem becomes more complex as number of alternatives and criteria in a problem increases.

\subsection{Finding Selection Criteria Weights}

The weights or importance degrees of criteria may be derived from different objective and subjective methods. In this paper, one of the subjective methods which is called SWARA (Step-wise Weight Assessment Ratio Analysis) is performed for getting criteria weights. This method was firstly introduced by Keršuliene et al. [57] for the rational dispute resolution method selection. The main difference of 
SWARA method from other similar methods is that decision makers choose their priorities according to the existing state of the environment. If the priorities of criteria are known former, the decisions about criteria and their priorities are made directly by SWARA method. The prime role on determining the criteria weights in this method belongs to a decision maker or an expert. Therefore, it is named as an expert oriented method [58-60].

Although many decision problems in the literature have been solved by performing SWARA method successfully, the development of SWARA-F method has been needed because of the nature of uncertainty in decision making. SWARA-F method is used to calculate the criteria weights in a fuzzy environment. It is also applicable for the problems including the group decision making [61]. SWARA-F method has been used for many problems in different areas due to be more appropriate to real case studies. These are outlined in Table 3.

Table 3. Existing SWARA-F studies

\begin{tabular}{|l|l|l|}
\hline Methods & Authors & Application Areas \\
\hline Fuzzy SWARA and Fuzzy MOORA & Mavi et al. [62] & Sustainable third-party reverse logistics provider selection \\
\hline Fuzzy SWARA and Fuzzy WASPAS & Mardani et al. [12], Ulutas [63], Agarwal et al. [64] & $\begin{array}{l}\text { Systematic review and meta-analysis, university website } \\
\text { performance evaluation, solutions evaluation to overcome } \\
\text { humanitarian supply chain management barriers }\end{array}$ \\
\hline Fuzzy SWARA and Fuzzy COPRAS & Zarbakhshnia et al. [65], Ansari et al. [66] & $\begin{array}{l}\text { Sustainable third-party reverse logistics provider } \\
\text { selection, sustainable remanufacturing supply chain }\end{array}$ \\
\hline Fuzzy SWARA and Fuzzy AD & Percin [61] & Outsourcing provider selection \\
\hline Fuzzy SWARA and WASPAS & Ren et al. [67] & Electric vehicle charging station site selection \\
\hline Fuzzy SWARA, Fuzzy TOPSIS, Fuzzy ARAS & Petrović et al. [68] & Supplier selection \\
\hline Fuzzy SWARA and Fuzzy ARAS & Ulutas [69] & Supplier selection \\
\hline Fuzzy SWARA and COPRAS & Rani et al. [70], Mishra et al. [71] & $\begin{array}{l}\text { Sustainable supplier selection, sustainability evaluation of } \\
\text { the bioenergy production process }\end{array}$ \\
\hline Fuzzy SWARA and CoCoSo & Llutas et al. [72] & Location selection \\
\hline Fuzzy SWARA and PROMETHEE & Ghasemi et al. [73] & Sustainable medical tourism destinations ranking \\
\hline
\end{tabular}

SWARA-F method requires same application steps as SWARA method. Researchers who need more information about SWARA method can refer to the article of Keršulienè et al. [57]. The main difference between SWARA and SWARA-F methods is employment of fuzzy numbers. The application steps of SWARA-F method are summarized as follows by assuming that there is a set of $n$ criteria $C_{j}(j=1,2, \ldots, n)$ in the problem $[62,65]$ :

Step 1. The decision maker is asked to rank the criteria from the best (ideal) to the worst (anti-ideal) by considering his/her expertise. Starting from the second criterion, the comparative importance levels are determined for each criterion by using fuzzy scale presented in Table 4 . This ratio represents the comparative importance of average value $\left(\widetilde{\mathrm{s}}_{\mathrm{j}}\right)$.

Table 4. Linguistic variables for comparative importance levels [74]

\begin{tabular}{|l|l|}
\hline Linguistic variable & Corresponding triangular fuzzy number \\
\hline Much less important & $(0.222,0.250,0.286)$ \\
\hline Very less important & $(0.286,0.333,0.400)$ \\
\hline Less important & $(0.400,0.500,0.667)$ \\
\hline Moderately less important & $(0.667,1.000,1.500)$ \\
\hline Equallv important & $(1.000,1.000,1.000)$ \\
\hline
\end{tabular}

Step 2. The fuzzy coefficient $\left(\tilde{k}_{j}\right)$ is calculated by considering each criterion as follows:

$$
\tilde{k}_{j}= \begin{cases}1 & \text { if } \quad \mathrm{j}=1 \\ \widetilde{s}_{j}+1 & \text { if } \quad \mathrm{j}>1\end{cases}
$$

Step 3. The fuzzy weight $\left(\tilde{q}_{j}\right)$ is calculated by considering each criterion as follows:

$$
\tilde{q}_{j}=\left\{\begin{array}{cc}
1 & \text { if } \mathrm{j}=1 \\
\frac{\tilde{q}_{j-1}}{\tilde{k}_{j}} & \text { if } \mathrm{j}>1 .
\end{array}\right.
$$

Step 4. The final fuzzy weight of each criterion $\left(\widetilde{w}_{j}\right)$ is calculated by dividing fuzzy weights $\left(\widetilde{q}_{j}\right)$ found in Step 3 by their sum 
$\widetilde{w}_{j}=\frac{\tilde{q}_{j}}{\sum \tilde{q}_{j}}$

The four steps mentioned above for SWARA-F are applied separately for each decision maker in the selection process. Thus, it can be said that number of criteria weight set is equal to number of decision makers. To continue the selection process, these different criteria weights sets need to be aggregated. The aggregation can be performed with different ways. In this study, weights of decision makers are performed during aggregation process. The weights of decision makers are also chosen to reflect decision maker's professional knowledge and experience. In this study, they are taken as crisp numbers and following formula is applied for aggregation purposes by assuming that there is a set of $K$ decision makers ( $\mathrm{k}=$ $1,2, \ldots, \mathrm{K})$ in the problem:

$\widetilde{w}_{j}=\sum_{k=1}^{K} w_{k} \widetilde{w}_{j}^{k}=\left(\sum_{k=1}^{K} w_{k} a_{j}^{k}, \sum_{k=1}^{K} w_{k} b_{j}^{k}, \sum_{k=1}^{K} w_{k} c_{j}^{k}\right), \quad(\mathrm{j}=1,2, \ldots, \mathrm{n} ; \mathrm{k}=1,2, \ldots, \mathrm{K})$.

In Equation (11), $\widetilde{w}_{j}$ is the aggregated fuzzy weight of $j$ th criterion. $\widetilde{w}_{j}^{k}$ presents fuzzy weight of $j$ th criterion which is determined by $k$ th decision maker and it is described by TFNs, $\widetilde{w}_{j}^{k}=\left(a_{j}^{k}, b_{j}^{k}, c_{j}^{k}\right)$. Finally, $w_{k}$ presents weight of $k$ th decision maker.

\subsection{Finding The Rank Order of the Alternatives}

MARCOS (Measurement Alternatives and Ranking according to the COmpromise Solution) is relatively new MCDM method. It was developed by Stević et al. [13]. This method determines preferability of alternatives by considering the relationship between alternatives and reference values. Defining decision making preferences is performed through utility functions. They show the position of an alternative relative to ideal and anti-ideal solutions [75]. The alternative closest to the ideal alternative and furthest from the anti-ideal alternative is the best [76]. Since it is a new method, there are few studies in the literature. These are outlined in Table 5 .

Table 5. Existing MARCOS-F studies

\begin{tabular}{|c|c|c|}
\hline Methods & Authors & Application Areas \\
\hline \multirow{5}{*}{ MARCOS } & \begin{tabular}{|l|} 
Stević et al. [13] \\
\end{tabular} & Sustainable supplier selection for the healthcare industry \\
\hline & Stević and Brković [76] & Personnel selection in logistic \\
\hline & Puška et al. [77] & Project management software evaluation \\
\hline & \begin{tabular}{|l|} 
Ulutaş et al. [78] \\
\end{tabular} & Stackers selection in a logistics system \\
\hline & $\begin{array}{ll}\text { Biswas [79] } \\
\end{array}$ & Performance measurement of healthcare supply chains \\
\hline \multirow{15}{*}{ Fuzzy MARCOS } & Stanković et al. [75] & Traffic risk assessment problem \\
\hline & Tlieva et al. [80] & Cloud service selection \\
\hline & Mitrović Simić et al. [81] & Safety evaluation of road sections \\
\hline & Simić et al. [82] & Risk assessment of railway infrastructure \\
\hline & Taş and Çakır [83] & Road risk analysis \\
\hline & Pamucar et al. [84] & Prioritization of alternatives for hydrogen bus development \\
\hline & Bakır and Atalik [85] & E-service quality evaluation in the airline industry \\
\hline & \begin{tabular}{|l|} 
Puška et al. [86] \\
\end{tabular} & Sustainable supplier selection \\
\hline & Tuş and Aytaç Adali [87] & Internet service provider selection problem \\
\hline & Ecer and Pamucar [88] & Insurance companies assessment \\
\hline & \begin{tabular}{|l} 
Celik and Gul [89] \\
\end{tabular} & Hazard identification, risk assessment and control for dam construction \\
\hline & \begin{tabular}{|l|} 
Gong et al. [90] \\
\end{tabular} & Renewable energy accommodation potential evaluation of distribution network \\
\hline & Ali [91] & Smartphone selection problem \\
\hline & Pamucar et al. [92] & Assessment of alternative fuel vehicles for sustainable road transportation \\
\hline & Deveci et al. [93] & Offshore wind farm site selection \\
\hline \multirow[t]{2}{*}{ Grey MARCOS } & Badi and Pamucar [94] & Supplier selection for the steelmaking company \\
\hline & Torkayesh et al. [95] & Landfill location selection for healthcare waste of urban areas \\
\hline D-MARCOS & Chakraborty et al. [96] & Supplier selection in an iron and steel industry \\
\hline
\end{tabular}

MARCOS-F, developed by Stanković et al. [75], defines fuzzy ideal and fuzzy anti-ideal reference values instead of crisp reference values differently from MARCOS method. It determines the relationships between alternatives and these fuzzy reference values and also defines the utility degrees of alternatives related with the fuzzy ideal and fuzzy anti-ideal solutions for ranking purpose. The steps of this method are as follows:

Step 1: The fuzzy decision matrix $\tilde{X}^{k}$ which includes fuzzy performances of different alternatives according to various criteria is formed by $k$ th decision maker by assuming that problem includes $m$ alternatives, $\mathrm{A}_{\mathrm{i}}(\mathrm{i}$ $=1,2, \ldots, \mathrm{m}), n$ criteria $\mathrm{C}_{\mathrm{j}}(\mathrm{j}=1,2, \ldots, \mathrm{n})$ and $K$ decision makers $\mathrm{DM}_{\mathrm{k}}(\mathrm{k}=1,2, \ldots, \mathrm{K})$. The decision makers use linguistic variables which are shown in Table 6 while evaluating the alternatives according to criteria. 
$\tilde{X}^{k}=\left[\tilde{x}_{i j}^{k}\right]_{m x n}=\left[\begin{array}{ccc}\tilde{x}_{11}^{k} & \cdots & \tilde{x}_{1 n}^{k} \\ \vdots & \ddots & \vdots \\ \tilde{x}_{m 1}^{k} & \cdots & \tilde{x}_{m m}^{k}\end{array}\right] \quad, \quad(\mathrm{i}=1,2 \ldots, \mathrm{m} ; \mathrm{j}=1,2, \ldots, \mathrm{n} ; \mathrm{k}=1,2, \mathrm{~K})$

$\tilde{x}_{i j}^{k}$ is the fuzzy performance value of $i$ th alternative on $j$ th criterion of the $k$ th decision maker and it is described by TFNs, $\tilde{x}_{i j}^{k}=\left(a_{i j}^{k}, b_{i j}^{k}, c_{i j}^{k}\right)$. To continue MARCOS-F method, different decision matrices need to be aggregated. In this study, weights of decision makers are taken into consideration during aggregation process as in previous section. The decision makers' weights in this section are still crisp numbers. Equation (14) is applied for finding the elements of group decision matrix $(\tilde{X})$. It is formed as:

$\tilde{X}=\left[\tilde{x}_{i j}\right]_{m x n}=\left[\begin{array}{ccc}\tilde{x}_{11} & \cdots & \tilde{x}_{1 n} \\ \vdots & \ddots & \vdots \\ \tilde{x}_{m 1} & \cdots & \tilde{x}_{m n}\end{array}\right] \quad(\mathrm{i}=1,2 \ldots, \mathrm{m} ; \mathrm{j}=1,2, \ldots, \mathrm{n})$,

$\tilde{x}_{i j}=\sum_{k=1}^{K} w_{k} \tilde{x}_{i j}^{k}=\left(\sum_{k=1}^{K} w_{k} a_{i j}^{k}, \sum_{k=1}^{K} w_{k} b_{i j}^{k}, \sum_{k=1}^{K} w_{k} c_{i j}^{k}\right)(\mathrm{i}=1,2, \ldots, \mathrm{m} ; \mathrm{j}=1,2, \ldots, \mathrm{n} ; \mathrm{k}=1,2, \ldots, \mathrm{K}),(14$

$\tilde{x}_{i j}$ is aggregated fuzzy performance value of $i$ th alternative on $j$ th criterion, $\tilde{x}_{i j}=\left(a_{i j}, b_{i j}, c_{i j}\right)$ and $w_{k}$ is weight of $k$ th decision maker.

Table 6. Linguistic variables for alternatives' performances evaluations [97]

\begin{tabular}{|l|l|}
\hline Rank & Corresponding triangular fuzzy number \\
\hline Very Low (VL) & $(0,0,0.25)$ \\
\hline Low $(\mathrm{L})$ & $(0,0.25,0.5)$ \\
\hline Medium $(\mathrm{M})$ & $(0.25,0.5,0.75)$ \\
\hline High $(\mathrm{H})$ & $(0.5,0.75,1)$ \\
\hline Very High $(\mathrm{VH})$ & $(0.75,1,1)$ \\
\hline
\end{tabular}

Step 2: An extended fuzzy group decision matrix is formed by adding ideal $\tilde{A}(I D)$ and anti-ideal $\tilde{A}(A I D)$ solutions. The alternative with the best and worst characteristics is called ideal solution and anti-ideal solution, respectively

$$
\tilde{X}=\left[\tilde{x}_{i j}\right]_{(m+1) x(n+1)}=\left[\begin{array}{ccc}
\tilde{x}_{A I D 1} & \ldots & \tilde{x}_{A I D n} \\
\tilde{x}_{11} & \ldots & \tilde{x}_{1 n} \\
\cdot & \ddots & . \\
\tilde{x}_{m 1} & \ldots & \tilde{x}_{m n} \\
\tilde{x}_{I D 1} & \ldots & \tilde{x}_{I D n}
\end{array}\right], \quad(\mathrm{i}=1,2 \ldots, \mathrm{m} ; \mathrm{j}=1,2, \ldots, \mathrm{n}) \text {. }
$$

Types of the criteria, maximization or minimization, are considered while determining $\tilde{A}(I D)$ and $\tilde{A}(A I D)$ solutions. The necessary procedure is as follows:

$$
\begin{array}{cl}
\text { for maximization criteria } & \tilde{A}(I D)=\max _{i} \tilde{x}_{i j} \\
& \tilde{A}(A I D)=\min _{i} \tilde{x}_{i j} \\
\text { for minimization criteria } & \tilde{A}(I D)=\min _{i} \tilde{x}_{i j} \\
& \tilde{A}(A I D)=\max _{i} \tilde{x}_{i j} .
\end{array}
$$

Step 3: Fuzzy normalized decision matrix $(\widetilde{N})$ is determined. Maximization and minimization criteria are normalized by Equations (18a)-(18b), respectively. In this study, it is preferred to use linear scale normalization formulas used in fuzzy TOPSIS method. The reason for performing this formula is the comparative analysis performed in the later section of the study. One of the methods in the comparative analysis section is fuzzy TOPSIS. It is thought that it would be correct to use the same normalization method in order to make the meaningful comparisons with the results of the fuzzy MARCOS method

$$
\begin{aligned}
& \widetilde{N}=\left[\tilde{n}_{i j}\right]_{m x n}, \\
& \tilde{n}_{i j}=\left(\frac{a_{i j}}{c_{j}^{*}}, \frac{b_{i j}}{c_{j}^{*}}, \frac{c_{i j}}{c_{j}^{*}}\right), \quad(\mathrm{i}=1,2 \ldots, \mathrm{m} ; \mathrm{j}=1,2, \ldots, \mathrm{n}),
\end{aligned}
$$


$\tilde{n}_{i j}=\left(\frac{a_{j}^{-}}{c_{i j}}, \frac{a_{j}^{-}}{b_{i j}}, \frac{a_{j}^{-}}{a_{i j}}\right), \quad(\mathrm{i}=1,2 \ldots, \mathrm{m} ; \mathrm{j}=1,2, \ldots, \mathrm{n})$,

$a_{j}^{-}=\min _{i} a_{i j}$

$c_{j}^{*}=\max _{i} c_{i j}$,

$\tilde{n}_{i j}$ is the normalized fuzzy performance values. The normalization formulas in Equations (18a) and (18b) provide the ranges of normalized TFNs are between $[0,1]$.

Step 4: The fuzzy weighted normalized decision matrix $\tilde{R}$ is calculated. $\tilde{r}_{i j}$ values are calculated by Equation (22):

$\tilde{R}=\left[\tilde{r}_{i j}\right]_{m x n}$

$\tilde{r}_{i j}=\widetilde{w}_{j} \tilde{n}_{\mathrm{ij}}$

where $\widetilde{w}_{\mathrm{j}}\left(0<\widetilde{w}_{\mathrm{j}}<1\right)$ is the weight of $j$ th criterion.

Step 5: The utility degree of each alternative $\left(\widetilde{K}_{i}\right)$ is computed by Equations (23a)-(23b)

$\widetilde{\mathrm{K}}_{\mathrm{i}}^{-}=\frac{\tilde{S}_{i}}{\tilde{S}_{A I D}}$

$\widetilde{\mathrm{K}}_{\mathrm{i}}^{+}=\frac{\tilde{S}_{i}}{\tilde{S}_{I D}}$

$\tilde{S}_{i}=\sum_{j=1}^{n} \tilde{r}_{i j}$.

Step 6: The total utility degree including both ideal and anti-ideal solutions of each alternative $\left(\tilde{T}_{i}\right)$ is computed by Equation (25):

$\widetilde{T}_{i}=\widetilde{\mathrm{K}}_{\mathrm{i}}^{-}+\widetilde{\mathrm{K}}_{\mathrm{i}}^{+}$.

To continue the operations, a new fuzzy representative value of total utility degrees is found as:

$\tilde{R}_{i}=\max _{i} \widetilde{T}_{i}$

Then $\widetilde{R}_{i}$ is defuzzified with Equation (7) and the crisp result is $R_{i}$.

Step 7: Utility functions for the ideal and anti-ideal solutions are computed by Equations (27a)-(27b), respectively

$f\left(\widetilde{K}_{i}^{+}\right)=\frac{\widetilde{\mathrm{K}}_{\mathrm{i}}^{-}}{R_{i}}$,

$f\left(\widetilde{K}_{i}^{-}\right)=\frac{\widetilde{K}_{i}^{+}}{R_{i}}$.

Step 8: The total utility of each alternative $f\left(K_{i}\right)$ is computed as follows:

$f\left(K_{i}\right)=\frac{K_{i}^{+}+K_{i}^{-}}{1+\frac{1-f\left(K_{i}^{+}\right)}{f\left(K_{i}^{+}\right)}+\frac{1-f\left(K_{i}^{-}\right)}{f\left(K_{i}^{-}\right)}}$,

$K_{i}^{+}, K_{i}^{-}, f\left(K_{i}^{+}\right)$and $f\left(K_{i}^{-}\right)$are defuzzified values of $\widetilde{K}_{i}^{+}, \widetilde{K}_{i}^{-}, f\left(\widetilde{K}_{i}^{+}\right)$and $f\left(\widetilde{K}_{i}^{-}\right)$respectively in Equation (28). The total utility of each alternative, $f\left(K_{i}\right)$, is used as the final assessment score of each alternative for ranking purposes. The one with the highest total utility value is the best alternative. 


\section{APPLICATION}

In this part, real case study is considered for applicability of SWARA-F and MARCOS-F in solving green supplier selection problems. A textile company operated in Denizli, Turkey is chosen as a real case study. The case company produces its own woven and knitted fabrics, converts them to the towel and bathrobe, and then exports them to European market. The company supplies many raw materials from its suppliers. The textile dyes, one of the main raw materials, are the subject of this study. Many foreign customers prefer to purchase green and environmental friendly textile products. The company searches the best green supplier for purchasing the textile dyes of its products. The main aim of this search is surviving in the competitive market and protecting the environment. An expert group of three people, managers from purchasing $\left(\mathrm{DM}_{1}\right)$, production $\left(\mathrm{DM}_{2}\right)$ and quality control $\left(\mathrm{DM}_{3}\right)$ departments, are responsible from identifying the green supplier alternatives and selecting the best supplier. Purchasing managers procure goods and services for resale or company use. Production managers provide technical management, supervision and control of production process. Quality control managers ensure products meet quality, reliability and performance standards. As mentioned before, weight values are assigned to each decision maker during the selection process to get more rational results. In this way, each decision maker can be part of the selection process as much as his/her own weight. In this study, their weights are considered as: $\mathrm{w}_{\mathrm{DM} 1}=0.3, \mathrm{w}_{\mathrm{DM} 2}=0.3$ and $\mathrm{w}_{\mathrm{DM} 3}=0.4$. Then, they determine the criteria by taking into account of the company's needs and existing green supplier management literature. There are four main criteria and their sub-criteria in the evaluation process:

- Cost $\left(\mathrm{C}_{1}\right)$ : Product price $\left(\mathrm{C}_{11}\right)$, Logistic cost $\left(\mathrm{C}_{12}\right)$

- Service $\left(\mathrm{C}_{2}\right)$ : Delivery on time $\left(\mathrm{C}_{21}\right)$, Flexibility and responsiveness $\left(\mathrm{C}_{22}\right)$

- Quality of the ingredient $\left(\mathrm{C}_{3}\right)$ : Conformance to specification $\left(\mathrm{C}_{31}\right)$, Product reliability $\left(\mathrm{C}_{32}\right)$, Packaging facilities $\left(\mathrm{C}_{33}\right)$

- Green criteria $\left(\mathrm{C}_{4}\right)$ : Environmental management system $\left(\mathrm{C}_{41}\right)$, Recycle rate $\left(\mathrm{C}_{42}\right)$, Green technology $\left(\mathrm{C}_{43}\right)$, Waste management system $\left(\mathrm{C}_{44}\right)$

The first three main criteria and related the sub-criteria are classical criteria as mentioned in Section 2. The fourth main criterion and related sub-criteria are the green criteria. Since the main purpose of this study is the selection of green suppliers, only the explanations of the fourth criterion and related sub-criteria are given in this section. In fact, general descriptions of these criteria are provided in Table 1. Green criteria $\left(\mathrm{C}_{4}\right)$ address the evaluation of environmental impact. Environmental management system $\left(\mathrm{C}_{41}\right)$ involves environmental certificates, environmental policies, planning, checking, and control of environmental activities. Recycle rate $\left(\mathrm{C}_{42}\right)$ is the percentage of product unit to be collected and recycled by the service provider. Green technology $\left(\mathrm{C}_{43}\right)$ is the type of technology that is considered environmentally friendly based on its production process or its supply chain. Finally, waste management system $\left(\mathrm{C}_{44}\right)$ is the strategy that an organization uses to dispose, reduce, reuse, and prevent waste. On the other hand, $\mathrm{C}_{11}, \mathrm{C}_{12}$ and $\mathrm{C}_{21}$ are minimization criteria while the others are maximization criteria. After investigating all potential suppliers, they determine five green supplier alternatives $\left(A_{1}, A_{2}, \ldots, A_{5}\right)$ for further analysis. The relative weights of main criteria given by $\mathrm{DM}_{1}$ with SWARA-F method are shown in Table 7. Tables 8-11 show local weights of sub-criteria given by $\mathrm{DM}_{1}$. These weights are obtained by using Equations (8)-(10). This process is same for the other decision makers, $\mathrm{DM}_{2}$ and $\mathrm{DM}_{3}$. Final weights of sub-criteria for all decision makers are presented in Table 12. These weights are aggregated by using Equation (11) and the results are shown in the last three column of Table 12 .

Table 7. Relative weights of main criteria for $D M_{1}$

\begin{tabular}{ccccc}
\hline & $\widetilde{s}_{j}$ & $\tilde{k}_{j}$ & $\tilde{q}_{j}$ & $\widetilde{w}_{j}$ \\
\hline $\mathrm{C}_{1}$ & & $(1.000,1.000,1.000)$ & $(1.000,1.000,1.000)$ & $(0.453,0.460,0.468)$ \\
$\mathrm{C}_{2}$ & $(1.000,1.000,1.000)$ & $(2.000,2.000,2.000)$ & $(0.500,0.500,0.500)$ & $(0.227,0.230,0.234)$ \\
$\mathrm{C}_{3}$ & $(0.286,0.333,0.400)$ & $(1.286,1.333,1.400)$ & $(0.357,0.375,0.389)$ & $(0.162,0.172,0.182)$ \\
$\mathrm{C}_{4}$ & $(0.222,0.250,0.286)$ & $(1.222,1.250,1.286)$ & $(0.278,0.300,0.318)$ & $(0.126,0.138,0.149)$ \\
\hline
\end{tabular}


Table 8. Local weights of cost for DM

\begin{tabular}{ccccc}
\hline & $\tilde{s}_{j}$ & $\tilde{k}_{j}$ & $\tilde{q}_{j}$ & $\widetilde{w}_{j}$ \\
\hline $\mathrm{C}_{11}$ & & $(1.000,1.000,1.000)$ & $(1.000,1.000,1.000)$ & $(0.563,0.571,0.583)$ \\
$\mathrm{C}_{12}$ & $(0.286,0.333,0.400)$ & $(1.286,1.333,1.400)$ & $(0.714,0.750,0.778)$ & $(0.402,0.429,0.454)$ \\
\hline
\end{tabular}

Table 9. Local weights of service for $D M_{1}$

\begin{tabular}{|c|c|c|c|c|c|c|c|c|c|c|c|c|}
\hline & & $\widetilde{s}_{j}$ & & & $\tilde{k}_{j}$ & & & $\tilde{q}_{j}$ & & & $\widetilde{w}_{j}$ & \\
\hline $\mathrm{C}_{21}$ & & & & $(1.000$ & 1.000 & $1.000)$ & $(1.000$ & 1.000 & $1.000)$ & $(0.583$ & 0.600 & $0.625)$ \\
\hline $\mathrm{C}_{22}$ & $(0.400$ & 0.500 & $0.667)$ & (1.400 & 1.500 & $1.667)$ & $(0.600$ & 0.667 & $0.714)$ & $(0.350$ & 0.400 & $0.446)$ \\
\hline
\end{tabular}

Table 10. Local weights of quality of the ingredient for $D M_{1}$

\begin{tabular}{ccccc}
\hline & $\widetilde{s}_{j}$ & $\tilde{k}_{j}$ & $\tilde{q}_{j}$ & $\widetilde{w}_{j}$ \\
\hline $\mathrm{C}_{31}$ & & $(1.000,1.000,1.000)$ & $(1.000,1.000,1.000)$ & $(0.493,0.545,0.610)$ \\
$\mathrm{C}_{32}$ & $(0.667,1.000,1.500)$ & $(1.667,2.000,2.500)$ & $(0.400,0.500,0.600)$ & $(0.197,0.273,0.366)$ \\
$\mathrm{C}_{33}$ & $(0.400,0.500,0.667)$ & $(1.400,1.500,1.667)$ & $(0.240,0.333,0.428)$ & $(0.118,0.182,0.261)$ \\
\hline
\end{tabular}

Table 11. Local weights of green criteria for $D M_{1}$

\begin{tabular}{ccccc}
\hline & $\widetilde{s}_{j}$ & $\tilde{k}_{j}$ & $\tilde{q}_{j}$ & $\widetilde{w}_{j}$ \\
\hline $\mathrm{C}_{41}$ & & $(1.000,1.000,1.000)$ & $(1.000,1.000,1.000)$ & $(0.375,0.400,0.438)$ \\
$\mathrm{C}_{42}$ & $(0.400,0.500,0.667)$ & $(1.400,1.500,1.667)$ & $(0.600,0.667,0.714)$ & $(0.225,0.267,0.313)$ \\
$\mathrm{C}_{43}$ & $(0.286,0.333,0.400)$ & $(1.286,1.333,1.400)$ & $(0.428,0.500,0.555)$ & $(0.161,0.200,0.243)$ \\
$\mathrm{C}_{44}$ & $(0.400,0.500,0.667)$ & $(1.400,1.500,1.667)$ & $(0.257,0.333,0.397)$ & $(0.096,0.133,0.174)$ \\
\hline
\end{tabular}

Table 12. Final weights of sub-criteria

\begin{tabular}{ccccc}
\hline & $\mathrm{DM}_{1}$ & $\mathrm{DM}_{2}$ & $\mathrm{DM}_{3}$ & Aggregated weights \\
\hline $\mathrm{C}_{11}$ & $(0.255,0.263,0.273)$ & $(0.156,0.171,0.192)$ & $(0.106,0.121,0.138)$ & $(0.166,0.179,0.195)$ \\
$\mathrm{C}_{12}$ & $(0.182,0.197,0.212)$ & $(0.094,0.114,0.137)$ & $(0.083,0.097,0.113)$ & $(0.116,0.132,0.150)$ \\
$\mathrm{C}_{21}$ & $(0.132,0.138,0.146)$ & $(0.064,0.082,0.099)$ & $(0.064,0.081,0.098)$ & $(0.085,0.098,0.113)$ \\
$\mathrm{C}_{22}$ & $(0.079,0.092,0.105)$ & $(0.046,0.061,0.077)$ & $(0.050,0.065,0.080)$ & $(0.057,0.072,0.087)$ \\
$\mathrm{C}_{31}$ & $(0.080,0.094,0.111)$ & $(0.151,0.165,0.185)$ & $(0.142,0.151,0.165)$ & $(0.126,0.138,0.155)$ \\
$\mathrm{C}_{32}$ & $(0.032,0.047,0.067)$ & $(0.091,0.110,0.132)$ & $(0.110,0.121,0.135)$ & $(0.081,0.096,0.114)$ \\
$\mathrm{C}_{33}$ & $(0.019,0.031,0.048)$ & $(0.065,0.082,0.103)$ & $(0.079,0.091,0.105)$ & $(0.057,0.070,0.087)$ \\
$\mathrm{C}_{41}$ & $(0.047,0.055,0.065)$ & $(0.068,0.081,0.096)$ & $(0.093,0.109,0.129)$ & $(0.072,0.084,0.100)$ \\
$\mathrm{C}_{42}$ & $(0.028,0.037,0.047)$ & $(0.049,0.061,0.075)$ & $(0.072,0.087,0.106)$ & $(0.052,0.064,0.079)$ \\
$\mathrm{C}_{43}$ & $(0.020,0.028,0.036)$ & $(0.029,0.040,0.054)$ & $(0.029,0.044,0.063)$ & $(0.026,0.038,0.052)$ \\
$\mathrm{C}_{44}$ & $(0.012,0.018,0.026)$ & $(0.023,0.032,0.044)$ & $(0.021,0.033,0.049)$ & $(0.019,0.028,0.041)$ \\
\hline
\end{tabular}

Before proceeding implementation steps of MARCOS-F method for ranking purpose, each decision maker is asked to assess the alternatives on the criteria basis. The linguistic variables in Table 6 are utilized while making these evaluations. The linguistic evaluations are presented in Table 13. These linguistic variables are translated into TFNs to be processed. Three different decision matrices belong to each decision maker are aggregated to get only one decision matrix. By using Equation (14), the weights of decision makers are considered during aggregation process. Then, ideal and anti-ideal solutions are determined and placed in the fuzzy group decision matrix. By this way, extended fuzzy decision matrix is formed and this matrix is normalized by using Equation (18a) and (18b) and weighted normalized fuzzy decision matrix is obtained by using Equation (22). Utility degree of each alternative $\left(\widetilde{\mathrm{K}}_{\mathrm{i}}\right)$ is computed by Equation (23a)-(23b); the total utility degree in terms of both ideal and anti-ideal solutions of each alternative $\left(\widetilde{T}_{i}\right)$ is computed by Equation (25); utility functions for ideal and anti-ideal solutions are computed by Equation (27a)-(27b); and lastly, the total utility of each alternative $f\left(K_{i}\right)$ is computed by Equation $(28) . \mathrm{K}_{\mathrm{i}}^{+}, \mathrm{K}_{\mathrm{i}}^{-}, \mathrm{f}\left(\mathrm{K}_{\mathrm{i}}^{+}\right)$and $\mathrm{f}\left(\mathrm{K}_{\mathrm{i}}^{-}\right)$ are defuzzified values of $\widetilde{\mathrm{K}}_{\mathrm{i}}^{+}, \widetilde{\mathrm{K}}_{\mathrm{i}}^{-}, \mathrm{f}\left(\widetilde{\mathrm{K}}_{\mathrm{i}}^{+}\right)$and $\mathrm{f}\left(\widetilde{\mathrm{K}}_{\mathrm{i}}^{-}\right)$computed with Equation $(7)$. According to $f\left(K_{i}\right)$ values in Table 14, alternatives are ranked and $\mathrm{A}_{1}$ is seen more appropriate than the other alternatives.

Table 13. Performances of green supplier alternatives on the criteria basis

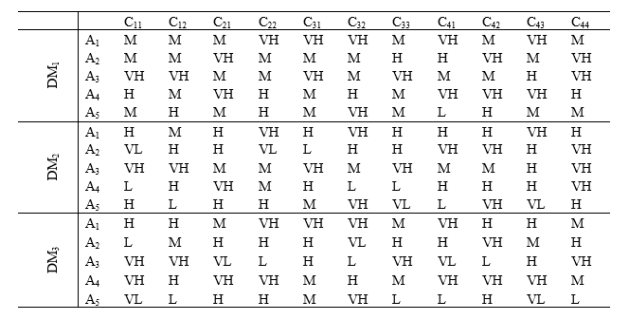


Table 14. Ranking of alternatives

\begin{tabular}{ccccccc}
\hline & $K_{i}^{-}$ & $K_{i}^{+}$ & $f\left(K_{i}^{-}\right)$ & $f\left(K_{i}^{+}\right)$ & $\mathrm{f}\left(\mathrm{K}_{\mathrm{i}}\right)$ & Ranking \\
\hline $\mathrm{A}_{1}$ & 2.821 & 0.917 & 0.238 & 0.733 & 0.820 & 1 \\
$\mathrm{~A}_{2}$ & 2.611 & 0.830 & 0.216 & 0.679 & 0.673 & 2 \\
$\mathrm{~A}_{3}$ & 2.297 & 0.738 & 0.192 & 0.597 & 0.516 & 5 \\
$\mathrm{~A}_{4}$ & 2.380 & 0.768 & 0.200 & 0.619 & 0.560 & 3 \\
$\mathrm{~A}_{5}$ & 2.340 & 0.745 & 0.194 & 0.608 & 0.531 & 4 \\
\hline
\end{tabular}

\section{SENSITIVITY AND COMPARATIVE ANALYSES}

Sensitivity analysis is performed to reveal changes in rank orders of the green supplier alternatives. Since decision makers' weight significantly affects the rank, changes of them should be evaluated. For this purpose, 36 different scenarios including different decision makers' weights are considered and they are shown in Table 15. At the same time, the same green supplier problem is solved also with CODAS-F, TOPSIS-F and EDAS-F methods to show the validity of MARCOS-F method. CODAS, TOPSIS, and EDAS methods are well known MCDM methods. CODAS method was developed by Keshavarz Ghorabaee et al. [98], TOPSIS method was developed by Hwang and Yoon [99] whereas EDAS method was developed by Keshavarz Ghorabaee et al. [100]. In the literature there are lots of successful applications of three methods. The common characteristic of three methods compared to MARCOS method is being distancebased methods. In other words, preferability of an alternative depends on the distance from Positive Ideal Solution (PIS) and Negative Ideal Solution (NIS) in TOPSIS method, average solution in EDAS method and NIS in CODAS method [101]. The same normalization procedure is utilized on three methods for the comparison purpose.

Table 15. 36 scenarios generated by different decision makers' weights

\begin{tabular}{|c|c|c|c|c|c|c|c|c|c|c|c|}
\hline Scenarios & & & & Scenarios & & & & Scenarios & & & \\
\hline 1 & $\mathrm{wDM}_{1}=0,1$ & $\mathrm{wDM}_{2}=0,1$ & $\mathrm{wDM} 3=0,8$ & 13 & $\mathrm{wDM}_{1}=0,2$ & $\mathrm{wDM}_{2}=0,5$ & $\mathrm{wDM} 3=0,3$ & 25 & $\mathrm{wDM}_{1}=0,4$ & $\mathrm{wDMM}_{2}=0,4$ & $\mathrm{wDNM}_{3}=0,2$ \\
\hline 2 & $\mathrm{wDM}_{1}=0,1$ & $\operatorname{wDM}_{2}=0,2$ & $\mathrm{wDM}_{3}=0,7$ & 14 & $\mathrm{wDM}_{1}=0,2$ & $\mathrm{wDM} 2=0,6$ & $\mathrm{wDM}_{3}=0,2$ & 26 & wDM $1=0,4$ & $\mathrm{wDMM}_{2}=0,5$ & $\mathrm{wDN}^{2}=0,1$ \\
\hline 3 & $\mathrm{wDM}_{1}=0,1$ & $\mathrm{wDM}_{2}=0,3$ & $\mathrm{wDM} 3=0,6$ & 15 & wDM $1=0,2$ & $\mathrm{wDM}_{2}=0,7$ & $\mathrm{wDM}_{3}=0,1$ & 27 & $\mathrm{wDM}_{1}=0,5$ & $\operatorname{wDM}_{2}=0,1$ & $\mathrm{wDM}_{3}=0,4$ \\
\hline 4 & $\operatorname{wDM}_{1}=0,1$ & $\mathrm{wDM}_{2}=0,4$ & $\mathrm{wDM}_{3}=0,5$ & 16 & $\mathrm{wDM}_{1}=0,3$ & $\mathrm{wDM} 2=0,1$ & $\mathrm{wDM}_{3}=0,6$ & 28 & wDM $1=0,5$ & $\mathrm{wDMM}_{2}=0,2$ & $\mathrm{wDM}=0,3$ \\
\hline 5 & $\operatorname{wDM}_{1}=0,1$ & $\mathrm{wDM}_{2}=0,5$ & $\mathrm{wDM}_{3}=0,4$ & 17 & $\mathrm{wDM}_{1}=0,3$ & $\mathrm{wDM} 2=0,2$ & $\mathrm{wDM}_{3}=0,5$ & 29 & $\operatorname{wDM} 1=0,5$ & $\mathrm{wDM}_{2}=0,3$ & $\mathrm{wDN}^{2}=0,2$ \\
\hline 6 & $\mathrm{wDMl}=0,1$ & $\mathrm{wDM}_{2}=0,6$ & $\mathrm{wDM} 3=0,3$ & 18 & $\mathrm{wDM} 1=0,3$ & $\operatorname{wDM}_{2}=0,3$ & $\mathrm{wDM}_{3}=0,4$ & 30 & $\mathrm{wDMl}=0,5$ & $\operatorname{wDM}^{2}=0,4$ & $\mathrm{wDMM}=0,1$ \\
\hline 7 & wDM $1=0,1$ & $\mathrm{wDM}_{2}=0,7$ & $\mathrm{wDM} / 3=0,2$ & 19 & $\mathrm{wDM}_{1}=0,3$ & $\mathrm{wDM} 2=0,4$ & $\mathrm{wDMM}_{3}=0,3$ & 31 & WDM $1=0,6$ & $\mathrm{wDM}_{2}=0,1$ & $\mathrm{wDM}^{2}=0,3$ \\
\hline 8 & $\mathrm{wDM}_{1}=0,1$ & $\mathrm{wDM}_{2}=0,8$ & $\mathrm{wDMM}_{3}=0,1$ & 20 & $\mathrm{wDNM}_{1}=0,3$ & $\mathrm{wDM} 2=0,5$ & $\mathrm{wDM}_{3}=0,2$ & 32 & WDM $1=0,6$ & $\mathrm{wDM}_{2}=0,2$ & $\mathrm{wDNM}^{2}=0,2$ \\
\hline 9 & $\mathrm{wDM}_{1}=0,2$ & $\mathrm{wDN}_{2}=0,1$ & $\mathrm{wDM}_{3}=0,7$ & 21 & $\mathrm{wDM}_{1}=0,3$ & $\mathrm{wDM}_{2}=0,6$ & $\mathrm{wDM} 33=0,1$ & 33 & $\mathrm{wDM}^{2}=0,6$ & $\operatorname{wDM}_{2}=0,3$ & $\mathrm{wDMM}_{3}=0,1$ \\
\hline 10 & $\mathrm{wDM}_{1}=0,2$ & $\operatorname{wDM}_{2}=0,2$ & $\mathrm{wDM} 3=0,6$ & 22 & $\mathrm{wDM}_{1}=0,4$ & $\mathrm{wDM} 2=0,1$ & $\mathrm{wDM}_{3}=0,5$ & 34 & $\mathrm{wDM}_{1}=0,7$ & $\mathrm{wDMM}_{2}=0,1$ & $\mathrm{wDN}=0,2$ \\
\hline 11 & $\mathrm{wDMl}=0,2$ & $\mathrm{wDMN}_{2}=0,3$ & $\mathrm{wDMM}_{3}=0,5$ & 23 & $\mathrm{wDMI}=0,4$ & $\mathrm{wDMM}_{2}=0,2$ & $\mathrm{wDMM}_{3}=0,4$ & 35 & $\mathrm{wDMI}^{\prime}=0,7$ & $\mathrm{wDMM}_{2}=0,2$ & wDM3 $^{2}=0,1$ \\
\hline 12 & $\operatorname{wDM}_{1}=0,2$ & $\mathrm{wDNN}^{2}=0,4$ & $\mathrm{wDM}_{3}=0,4$ & 24 & wDM $1=0,4$ & $\operatorname{wDM}_{2}=0,3$ & $\mathrm{wDM} 3=0,3$ & 36 & wDM1 $=0,8$ & $\operatorname{wDM}_{2}=0,1$ & $\mathrm{wDN}_{3}=0,1$ \\
\hline
\end{tabular}

TOPSIS-F method proposed by Chen [102], EDAS-F method proposed by Keshavarz Ghorabaee et al. [103] and finally CODAS-F method proposed by Keshavarz Ghorabaee et al. [104] have been applied. In CODAS-F method, threshold parameter value is taken as 0.02 . The ranking results of proposed method and other methods are presented in Figures 1-4, separately. Figure 5 also presents the comparative analysis of the Scenario 18 in a simpler way. This scenario consists of decision-making weights, which are given in the application section of the study. As it can be seen in Figures 1-4, the ranks of green supplier alternatives change in different methods depending on decision makers' weights. The rankings of $A_{1}$ and $A_{2}$ do not change in almost all of the alternative rankings that occurred under different methods and different decisionmakers' weights. $A_{1}$ is the best alternative in 36 scenarios. $A_{3}, A_{4}$ and $A_{5}$ take the last place in some rankings. On the other hand, MARCOS-F method also produces a ranking compatible with other distance based-methods. The solution of MARCOS-F gives the first and second orders to $A_{1}$ and $A_{2}$ regardless of the change in weight of decision makers.

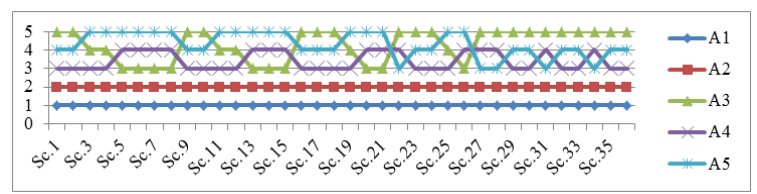

Figure 1. The ranking results of MARCOS $-F$ method 


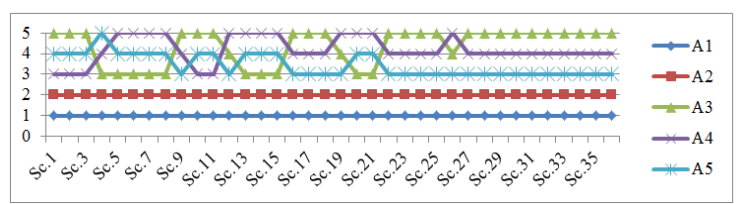

Figure 2. The ranking results of CODAS -F method

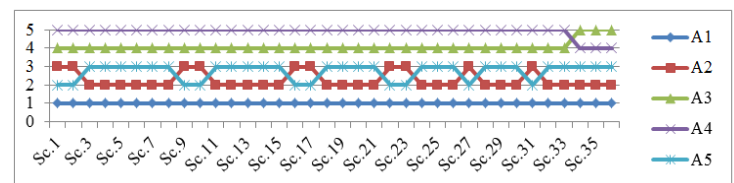

Figure 3. The ranking results of EDAS -F method

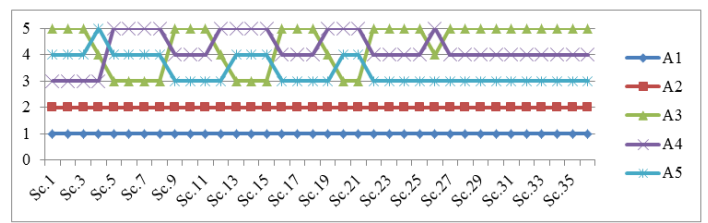

Figure 4. The ranking results of TOPSIS-F method

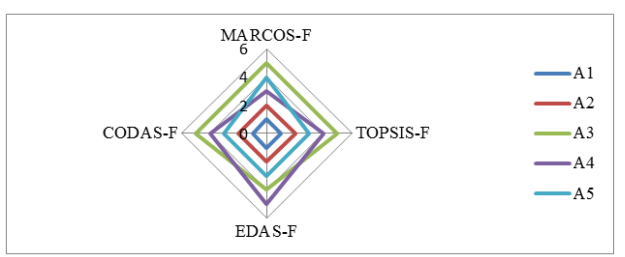

Figure 5. Radar chart for the ranking in terms of different methods (Scenario 18)

\section{DISCUSSION AND MANAGERIAL IMPLICATIONS}

Green supplier selection integrates environmental thinking into traditional supplier selection and it is very important in terms of environmental protection and sustainable development due to increasing consumption levels. The aim of this study is to propose an applicable and combined methodology for green supplier selection and demonstrate a solution of a problem. The data is collected from a textile company in Denizli. Both general and environmental selection criteria are considered. We analyze the criteria affecting the green supplier selection decision by determining the importance levels of these criteria after a detailed literature review. We use SWARA-F method instead of classic SWARA method to determine the criteria weights. The main reason of using SWARA-F method is to consider the expected significance of the criteria decided by the experts. From this point of view, SWARA, decision oriented method, is a suitable research method for this study. In addition, the method is suitable for finding the criteria weights of group decision-making problems in a fuzzy environment. The results show that the cost is the most important main criterion for the textile firm. Service, quality of ingredient and green criteria follow this criterion, respectively. Product price is the most important among the sub-criteria. Environmental management system is the most important sub-criterion when we evaluate the green main criterion in itself. Recycle rate, green technology and waste management system follow this criterion, respectively. Environmental management system subcriterion is more important than flexibility and responsiveness which is the sub-criterion of service and packaging facilities which is the sub-criterion of quality of ingredient. We consider many criteria and provide richer explanations in terms of examining the impact of significances on green supplier evaluation. On the other hand, green supplier alternatives are ranked with MARCOS-F method according to the total utility degree of each alternative, considering the uncertainty in real life. Also, the supplier that does not meet the requirements of the textile company is determined. This output can also be used to analyze the supplier's shortcomings and identify aspects which are improved for their performance. There are many advantages of the MARCOS-F method over other MCDM methods. This method considers of fuzzy ideal and fuzzy anti-ideal solutions as reference values, determines them at early stage of decision matrix, capture the best alternative with utility functions namely utility degrees by using both reference values. MARCOS- 
F method is compared with CODAS-F, TOPSIS-F and EDAS-F methods to check for the validity purpose. In addition, the data are measured consistently with the sensitivity analysis performed with different decision makers' weight sets. The fact that the best green supplier is in the same order with the sensitivity analyzes performed shows the consistency of the results. Small changes in rankings will not make a significant difference in the selection. The empirical results indicate that SWARA-F and MARCOS-F methods have great practical value for green supplier selection in a textile firm with uncertain and complex information and also provide flexibility in decision making. From this point of view, we contribute to the relevant literature by presenting new findings and provide usable suggestions for solving a selection problem on a popular topic. The findings can be used to improve firms' experience with green supplier selection. Therefore, these data allow for a more detailed and meaningful analysis. This study also provides important implications for many companies in different sectors. By considering these methods, managers can successfully solve different types of selection problems that they encounter in real-time production and service environments. It should be noted that we must pay attention while interpreting the findings mentioned above. The limitations of this study can be summarized as follows. Our study is limited a single textile firm. For each firm, the suppliers will be different. The criteria in this study are formed by the expert group consisting of only three department managers of the firm and there are no direct effects of customers or suppliers to this process. So, the results depend on their experiences and observations. Individual differences due to personal preferences and choices may cause different results in group decision making. Different criteria may be considered when evaluating green suppliers. Therefore, criteria should be updated and re-evaluated in each study for future researches. Number of criteria may be increased based on users' needs. The relationships between the criteria are not taken into account.

\section{CONCLUSION AND FUTURE RESEARCH}

The success of the GSCM mostly depends on suitable green supplier selection. Therefore, the green criteria should also be taken into consideration besides the classical criteria in the evaluation and selection processes. In this study, SWARA-F is combined with MARCOS-F for the evaluation green suppliers' alternatives and selection the best one among them. To demonstrate the proposed methodology, a supplier selection problem of a textile company is solved. The same problem is solved with CODAS-F, TOPSIS-F and EDAS-F methods to perform comparative analyses. Also, sensitivity of the decision makers' weights in the problem is tried to measure. Consequently, proposed methodology is not difficult to apply in spite of the uncertain experts' opinions in the evaluation process. Compared with existing literature, it provides a new way for evaluation and selection of green suppliers. It is thought that combined methodology can be applied to other MCDM problems due to its flexible, simple, and stable characteristics against changes. It is useful for decision makers to rank alternatives by efficiently addressing the problem. Although the proposed methodology is efficient in selecting the most reasonable green supplier and the results obtained from this study are satisfactory for the textile firm, there are aspects of the study that are open to improvement. More complex selection problems including more main and sub criteria may be solved, the solution power of the proposed methodology may be measured. The sensitivity analyses based on changes on criteria weights may be performed by this way, robustness of proposed methodology may be revealed. Different types of both MCDM problems and also problems in different areas such as economy, finance etc. may be solved. Different types of fuzzy memberships, fuzzy numbers, and defuzzification methods may be performed.

\section{CONFLICTS OF INTEREST}

No conflict of interest was declared by the authors.

\section{REFERENCES}

[1] Quan, J., Zeng, B., Liu, D., "Green supplier selection for process industries using weighted grey incidence decision model", Complexity, 2018: 1-12, (2018).

[2] Christopher, M., "Logistics \& Supply Chain Management", 5th Edition, UK: Pearson, (2016). 
[3] Ketikidis, P. H., Koh, S.C.L, Dimitriadis, N., Gunasekarand, A., Kehajova, M., "The use of information systems for logistics and supply chain management in South East Europe: Current status and future direction", Omega, 36: 592-599, (2008).

[4] Buyukozkan, G., Cifci, G., "A novel hybrid MCDM approach based on fuzzy DEMATEL, fuzzy ANP and fuzzy TOPSIS to evaluate green suppliers", Expert Systems with Applications, 39(3): 30003011, (2012).

[5] Zafar, A., Zafar, M., Sarwar, A., Raza, H., Khan, M.T., "A Fuzzy AHP method for green supplier selection and evaluation", Proceedings of the $12^{\text {th }}$ International Conference on Management Science and Engineering Management, Australia, 1355-1366, (2019).

[6] Kannan, D., Govindan, K., Rajendran, S., "Fuzzy axiomatic design approach based green supplier selection: A case study from Singapore", Journal of Cleaner Production, 96: 194-208, (2015).

[7] Galankashi, M. R., Chegeni, A., Soleimanynanadegany, A., Memari, A., Anjomshoae, A., Helmi, S. A., Dargi, A., "Prioritizing green supplier selection criteria using fuzzy analytical network process", Procedia CIRP, 26: 689-694, (2015).

[8] Chaharsooghi, S. K., Ashrafi, M., "Sustainable supplier performance evaluation and selection with neofuzzy TOPSIS method”, International Scholarly Research Notices, 434168: 1-10, (2014).

[9] Chin, T.A., Tat, H. H., Sulaiman, Z., "Green supply chain management, environmental collaboration and sustainability performance”, Procedia CIRP, 26: 695-699, (2015).

[10] Arshadi Khamseh, A., Mahmoodi, M., "A new fuzzy TOPSIS-TODIM hybrid method for green supplier selection using fuzzy time function”, Advances in Fuzzy Systems, 841405: 1-10, (2014).

[11] Zadeh, L.A., "Fuzzy sets", Information and Control, 8: 338-353, (1965).

[12] Mardani, A., Nilashi, M., Zakuan, N., Loganathan, N., Soheilirad, S., Saman, M.Z.M., Ibrahim, O., "A systematic review and meta-Analysis of SWARA and WASPAS methods: Theory and applications with recent fuzzy developments", Applied Soft Computing, 57: 265-292, (2017).

[13] Stević, Ž., Pamučar, D., Puška, A., Chatterjee, P., "Sustainable supplier selection in healthcare industries using a new MCDM method: Measurement of alternatives and ranking according to Compromise solution (MARCOS)", Computers \& Industrial Engineering, 140: 106231, (2020).

[14] Bali, O., Kose, E., Gumus, S., "Green supplier selection based on IFS and GRA", Grey Systems: Theory and Application, 3(2): 158-176, (2013).

[15] Banaeian, N., Mobli, H., Fahimnia, B., Nielsen, I. E., Omid, M., "Green supplier selection using fuzzy group decision making methods: A case study from the agri-food industry", Computers \& Operations Research, 89: 337-347, (2018).

[16] Sarwar, A., Xu, J., Zeng, Z., Hashim, M., "AHP and fuzzy TOPSIS methods for green supplier selection and evaluation", International Journal of Advanced Research, 5(3): 625-635, (2017).

[17] Sun, Y., Cai, Y., “A flexible decision-making method for green supplier selection integrating TOPSIS and GRA under the single-valued neutrosophic environment", IEEE Access, 9: 83025-83040, (2021).

[18] Tuzkaya, G., Ozgen, A., Ozgen, D., Tuzkaya, U. R., "Environmental performance evaluation of suppliers: a hybrid fuzzy multi-criteria decision approach", International journal of Environmental Science and Technology, 6: 477-490, (2009). 
[19] Gao, H., Ju, Y., Gonzalez, E.D.S., Zhang, W., “Green supplier selection in electronics manufacturing: An approach based on consensus decision making", Journal of Cleaner Production, 245: 118781, (2020).

[20] Kannan, D., Khodaverdi, R., Olfat, L., Jafarian, A., Diabat, A., "Integrated fuzzy multi criteria decision making method and multi-objective programming approach for supplier selection and order allocation in a green supply chain", Journal of Cleaner Production, 47: 355-367, (2013).

[21] Mohammed, A., Harris, I., Soroka, A., Naim, M. M., Ramjaun, T., "Evaluating green and resilient supplier performance: AHP-fuzzy TOPSIS decision-making approach", Proceedings of the $7^{\text {th }}$ International Conference on Operations Research and Enterprise Systems (ICORES), Portugal, 209216, (2018).

[22] Qin, J., Liu, X., Pedrycz, W., “An extended TODIM multi-criteria group decision making method for green supplier selection in interval type-2 fuzzy environment", European Journal of Operational Research, 258(2): 626-638, (2017).

[23] Xu, D., Cui, X., Xian, H., "An extended EDAS method with a single-valued complex neutrosophic set and its application in green supplier selection", Mathematics, 8(2): 282, (2020).

[24] Javad, M. O. M., Darvishi, M., Javad, A. O. M., "Green supplier selection for the steel industry using BWM and fuzzy TOPSIS: A case study of Khouzestan steel company", Sustainable Futures, 2, 100012, (2020).

[25] Akcan, S., Taş, M. A., "Green supplier evaluation with SWARA-TOPSIS integrated method to reduce ecological risk factors", Environmental Monitoring and Assessment, 191(12): 1-22, (2019).

[26] Yazdani, M., Hashemkhani Zolfani, S., Zavadskas, E. K., "New integration of MCDM methods and QFD in the selection of green suppliers", Journal of Business Economics and Management, 17(6): 1097-1113, (2016).

[27] Duan, C. Y., Liu, H. C., Zhang, L. J., Shi, H., "An extended alternative queuing method with linguistic Z-numbers and its application for green supplier selection and order allocation", International Journal of Fuzzy Systems, 21(8): 2510-2523, (2019).

[28] Dogan, A., Soylemez, I., Ozcan, U., "Green supplier selection by using fuzzy Topsis method", Uncertainty Modelling in Knowledge Engineering and Decision Making: Proceedings of the $12^{\text {th }}$ International FLINS Conference, France, 638-645, (2016).

[29] Mousakhani, S., Nazari-Shirkouhi, S., Bozorgi-Amiri, A., "A novel interval type-2 fuzzy evaluation model based group decision analysis for green supplier selection problems: A case study of battery industry", Journal of Cleaner Production, 168: 205-218, (2017).

[30] Yucesan, M., Mete, S., Serin, F., Celik, E., Gul, M., "An integrated best-worst and interval type-2 fuzzy TOPSIS methodology for green supplier selection”, Mathematics, 7: 182, (2019).

[31] Rouyendegh, B. D., Yildizbasi, A., Üstünyer, P., "Intuitionistic fuzzy TOPSIS method for green supplier selection problem", Soft Computing, 24(3): 2215-2228, (2020).

[32] Vishnu, V. A., Babu, J., George, B., "Green supplier selection using hybrid grey relational analysis with fuzzy logic method", IOP Conference Series: Materials Science and Engineering, IOP Publishing, 396(1): 012073, (2018).

[33] Ecer, F., "Multi-criteria decision making for green supplier selection using interval type-2 fuzzy AHP: a case study of a home appliance manufacturer", Operational Research, 1-35, (2020). 
[34] Mina, H., Mirabedin, S.N., Pakzad-Moghadam, S.H., "An integrated fuzzy analytic network process approach for green supplier selection: A case study of petrochemical industry", Journal of Management Science and Practice, 2(2): 31-47, (2014).

[35] Ustunyer, P., Eraslan, E., Erdebilli, B., Yildizbas, A., "Intuitionistic fuzzy ELECTRE method for green supplier selection problem", Proceedings of the $11^{\text {th }}$ International NCM Conferences, Ankara, 89, (2018).

[36] Yu, M. C., Su, M. H., "Using fuzzy DEA for green suppliers selection considering carbon footprints", Sustainability, 9(4): 495, (2017).

[37] Sen, D. K., Datta, S., Patel, S. K., Mahapatra, S. S., "Green supplier selection in fuzzy context: a decision-making scenario on application of fuzzy-MULTIMOORA", International Journal of Services and Operations Management, 28(1): 98-140, (2017).

[38] Beng, L.G., Badrul, O., "Green supplier selection: analysis of qualitative environmental criteria using fuzzy axiomatic approach”, Applied Mechanics and Materials, 465: 1054-1059, (2014).

[39] Guo, Z., Liu, H., Zhang, D., Yang, J., "Green supplier evaluation and selection in apparel manufacturing using a fuzzy multi-criteria decision-making approach", Sustainability, 9(4): 650, (2017).

[40] Sang, X., Liu, X., "An interval type-2 fuzzy sets-based TODIM method and its application to green supplier selection”, Journal of the Operational Research Society, 67(5): 722-734, (2016).

[41] Keshavarz Ghorabaee, M., Zavadskas, E. K., Amiri, M., Esmaeili, A., "Multi-criteria evaluation of green suppliers using an extended WASPAS method with interval type-2 fuzzy sets", Journal of Cleaner Production, 137: 213-229, (2016).

[42] Mishra, A. R., Rani, P., Pardasani, K. R., Mardani, A., "A novel hesitant fuzzy WASPAS method for assessment of green supplier problem based on exponential information measures", Journal of Cleaner Production, 238: 117901, (2019).

[43] Kumari, R., Mishra, A.R., "Multi-criteria COPRAS method based on parametric measures for intuitionistic fuzzy sets: application of green supplier selection”, Iranian Journal of Science and Technology, Transactions of Electrical Engineering, 44(4): 1645-1662, (2020).

[44] Shaw, K., Shankar, R., Yadav, S. S., Thakur, L.S., "Supplier selection using fuzzy AHP and fuzzy multi-objective linear programming for developing low carbon supply chain", Expert Systems with Applications, 39(9): 8182-8192, (2012).

[45] Mavi, R. K., "Green supplier selection: a fuzzy AHP and fuzzy ARAS approach", International Journal of Services and Operations Management, 22(2): 165-188, (2015).

[46] Gavareshki, M. H. K., Hosseini, S. J., Khajezadeh, M., "A case study of green supplier selection method using an integrated ISM-Fuzzy MICMAC analysis and multi-criteria decision making”, International Journal of Management Science and Engineering,16(4): 562-573, (2017).

[47] Lo, H.W., Liou, J. J., Wang, H. S., Tsai, Y.S., "An integrated model for solving problems in green supplier selection and order allocation", Journal of Cleaner Production, 190: 339-352, (2018).

[48] Gupta, S., Soni, U., Kumar, G., "Green supplier selection using multi-criterion decision making under fuzzy environment: A case study in automotive industry", Computers \& Industrial Engineering, 136: 663-680, (2019). 
[49] Đalić, I., Stević, Ž., Karamasa, C., Puška, A., "A novel integrated fuzzy PIPRECIA-interval rough SAW model: Green supplier selection", Decision Making: Applications in Management and Engineering, 3(1): 126-145, (2020).

[50] Qu, G., Zhang, Z., Qu, W., Xu, Z., "Green supplier selection based on green practices evaluated using fuzzy approaches of TOPSIS and ELECTRE with a case study in a Chinese internet company", Journal of Environmental and Public Health, 17(9): 3268, (2020).

[51] Liao, H. C., Ren, R. X., Antucheviciene, J., Šaparauskas, J., Al-Barakati, A., "Sustainable construction supplier selection by a multiple criteria decision-making method with hesitant linguistic information", Economics and Management, 23(4): 119-136, (2020).

[52] Zimmermann, H. J., "Fuzzy Set Theory and its Applications", 2ndEdition, Boston: Kluwer Academic Publishers, 57, (1992).

[53] Kaufmann, A., Gupta, M. M., "Fuzzy Mathematical Models in Engineering and Management Science”, 1st Edition, Amsterdam: Elsevier Science Publishers B.V., 28, 56-60, (1988).

[54] Maheswari, S., Shalini, M., Yookesh, T. L., "Defuzzification formula for modelling and scheduling a furniture fuzzy project network", International Journal of Engineering and Advanced Technology, 9 (1S5): 279-283, (2019).

[55] Chen, S. H., Hsieh, C. H., "Representation, ranking, distance, and similarity of L-R type fuzzy number and application", Australian Journal of Intelligent Information Processing Systems, 6 (4): 217-229, (2000).

[56] Chou, T. Y., Hsu, C. L., Chen, M. C., "A fuzzy multi-criteria decision model for international tourist hotels location selection", International Journal of Hospitality Management, 27(2): 293-301, (2008).

[57] Keršuliene, V., Zavadskas, E. K., Turskis, Z., "Selection of rational dispute resolution method by applying new stepwise weight assessment ratio analysis (SWARA)", Journal of Business Economics and Management, 11(2): 243-258, (2010).

[58] Zolfani, S. H., Saparauskas, J., "New application of SWARA method in prioritizing sustainability assessment indicators of energy system", Engineering economics, 24(5): 408-414, (2013).

[59] Zolfani, S. H., Zavadskas, E. K., "Sustainable development of rural areas' building structures based on local climate", Procedia Engineering, 57: 1295-1301, (2013).

[60] Zolfani, S. H., Banihashemi, S. S. A., "Personnel selection based on a novel model of game theory and MCDM approaches", Proceedings of the $8^{\text {th }}$ International Scientific Conference: Business and Management, Lithuania, 191-198, (2014).

[61] Percin, S., "An integrated fuzzy SWARA and fuzzy AD approach for outsourcing provider selection", Journal of Manufacturing Technology Management, 30(2): 531-552, (2019).

[62] Mavi, R.K., Goh, M., Zarbakhshnia, N., "Sustainable third-party reverse logistic provider selection with fuzzy SWARA and fuzzy MOORA in plastic industry", The International Journal of Advanced Manufacturing, 91(5-8): 2401-2418, (2017).

[63] Ulutas, A., "University website performance evaluation using fuzzy SWARA and WASPAS-F", In Book Multi-Criteria Decision-Making Models for Website Evaluation, 151-165, IGI Global, (2019). 
[64] Agarwal, S., Kant, R., Shankar, R., "Evaluating solutions to overcome humanitarian supply chain management barriers: A hybrid fuzzy SWARA-fuzzy WASPAS approach", International Journal of Disaster Risk Reduction, 51, 101838, (2020).

[65] Zarbakhshnia, N., Soleimani, H., Ghaderi, H., "Sustainable third-party reverse logistics provider evaluation and selection using fuzzy SWARA and developed fuzzy COPRAS in the presence of risk criteria", Applied Soft Computing, 65: 307-319, (2018).

[66] Ansari, Z. N, Kant, R., Shankar, R., "Evaluation and ranking of solutions to mitigate sustainable remanufacturing supply chain risks: a hybrid fuzzy SWARA-fuzzy COPRAS framework approach", International Journal of Sustainable Engineering, 13(6): 473-494, (2020).

[67] Ren, R. X., Liao, H. C., Al-Barakati, A., Cavallaro, F., "Electric vehicle charging station site selection by an integrated hesitant fuzzy SWARA-WASPAS Method", Transformations in Business \& Economics, 18(2): 103-123, (2019).

[68] Petrović, G., Mihajlović, J., Ćojbašić, Ž., Madić, M., Marinković, D., “Comparison of three fuzzy MCDM methods for solving the supplier selection problem", Facta Universitatis, Series: Mechanical Engineering, 17(3): 455-469, (2019).

[69] Ulutas, A., "Using of fuzzy SWARA and fuzzy ARAS methods to solve supplier selection problem", In Theoretical and Applied Mathematics in International Business, 136-148, IGI Global, (2020).

[70] Rani, P., Mishra, A. R., Krishankumar, R., Mardani, A., Cavallaro, F., Ravichandran, K. S., Balasubramanian, K., "Hesitant fuzzy SWARA-complex proportional assessment approach for sustainable supplier selection (HF-SWARA-COPRAS)", Symmetry, 12(7): 1152, (2020).

[71] Mishra, A. R., Rani, P., Pandey, K., Mardani, A., Streimikis, J., Streimikiene, D., Alrasheedi, M., "Novel multicriteria intuitionistic fuzzy SWARA-COPRAS approach for sustainability evaluation of the bioenergy production process", Sustainability, 12(10): 4155, (2020).

[72] Ulutas, A., Karakus, C. B., Topal, A., "Location selection for logistics center with fuzzy SWARA and CoCoSo methods", Journal of Intelligent \& Fuzzy Systems, 38(4): 4693-4709, (2020).

[73] Ghasemi, P., Mehdiabadi, A., Spulbar, C., Birau, R., "Ranking of sustainable medical tourism destinations in Iran: An integrated approach using fuzzy SWARAPROMETHEE", Sustainability, 13(2): 683, (2021).

[74] Chang, D.Y., "Applications of the extent analysis method on fuzzy AHP”, European Journal of Operational Research, 95(3): 649-655, (1996).

[75] Stanković, M., Stević, Ž., Das, D.K., Subotić, M., Pamučar, D., “A new fuzzy MARCOS method for road traffic risk analysis", Mathematics, 8(3): 457, (2020).

[76] Stević, Ž., Brković, N., "A novel integrated FUCOM-MARCOS model for evaluation of human resources in a transport company", Logistics, 4(1): 4, (2020).

[77] Puška, A., Stojanović, I., Maksimović, A., Osmanović, N., "Evaluation software of project management used measurement of alternatives and ranking according to compromise solution (MARCOS) method", Operational Research in Engineering Sciences: Theory and Applications, 3(1): 89-102, (2020).

[78] Ulutas, A., Karabasevic, D., Popovic, G., Stanujkic, D., Nguyen, P. T., Karakoy, Ç., "Development of a novel integrated CCSD-ITARA-MARCOS decision-making approach for stackers selection in a logistics system", Mathematics, 8(10): 1672, (2020). 
[79] Biswas, S., "Measuring performance of healthcare supply chains in India: A comparative analysis of multi-criteria decision making methods", Decision Making: Applications in Management and Engineering, 3(2): 162-189, (2020).

[80] Ilieva, G., Yankova, T., Hadjieva, V., Doneva, R., Totkov, G., "Cloud service selection as a fuzzy multi-criteria problem", TEM Journal, 9 (2): 484-495, (2020).

[81] Mitrović Simić, J., Stević, Ž., Zavadskas, E.K., Bogdanović, V., Subotić, M., Mardani, A., “A novel CRITIC-Fuzzy FUCOM-DEA-Fuzzy MARCOS model for safety vvaluation of road sections based on geometric parameters of road", Symmetry, 12(12): 2006, (2020).

[82] Simić, V., Soušek, R., Jovčić, S., "Picture fuzzy MCDM approach for risk assessment of railway infrastructure", Mathematics, 8(12): 2259, (2020).

[83] Taş, M. A., Çakır, E., "Ranking Triangular and Trapezoidal Fuzzy MARCOS Methods on Road Risk", In 2021 IEEE 6th International Forum on Research and Technology for Society and Industry (RTSI), 370-375, IEEE, (2021).

[84] Pamucar, D., Iordache, M., Deveci, M., Schitea, D., Iordache, I., “A new hybrid fuzzy multi-criteria decision methodology model for prioritizing the alternatives of the hydrogen bus development: A case study from Romania”, International Journal of Hydrogen Energy, 46(57): 29616-29637, (2021).

[85] Bakır, M., Atalık, Ö., "Application of fuzzy AHP and fuzzy MARCOS approach for the evaluation of e-service quality in the airline industry", Decision Making: Applications in Management and Engineering, 4(1): 127-152, (2021).

[86] Puška, A., Stević, Ž., Stojanović, I., "Selection of sustainable suppliers using the fuzzy MARCOS method", Current Chinese Science, 1(2): 218-229, (2021).

[87] Tuş, A., Aytaç Adalı, E., "İnternet servis sağlayıcı seçim probleminin çözümünde bulanık sıralama ağırlık tabanlı bulanık MARCOS yöntemi”, Politeknik Dergisi, 1-1, (2021). DOI: 10.2339/politeknik.881609

[88] Ecer, F., Pamucar, D., "MARCOS technique under intuitionistic fuzzy environment for determining the COVID-19 pandemic performance of insurance companies in terms of healthcare services", Applied Soft Computing, 104, 107199, (2021).

[89] Celik, E., Gul, M., "Hazard identification, risk assessment and control for dam construction safety using an integrated BWM and MARCOS approach under interval type-2 fuzzy sets environment", Automation in Construction, 127: 103699 (2021).

[90] Gong, X., Yang, M., Du, P., "Renewable energy accommodation potential evaluation of distribution network: A hybrid decision-making framework under interval type-2 fuzzy environment", Journal of Cleaner Production, 286: 124918, (2021).

[91] Ali, J., "A novel score function based CRITIC-MARCOS method with spherical fuzzy information", Computational and Applied Mathematics, 40(8): 1-27, (2021).

[92] Pamucar, D., Ecer, F., Deveci, M., "Assessment of alternative fuel vehicles for sustainable road transportation of United States using integrated fuzzy FUCOM and neutrosophic fuzzy MARCOS methodology", Science of The Total Environment, 788, 147763, (2021). 
[93] Deveci, M., Özcan, E., John, R., Pamucar, D., Karaman, H., "Offshore wind farm site selection using interval rough numbers based Best Worst Method and MARCOS”, Applied Soft Computing, 107532, (2021).

[94] Badi, I., Pamucar, D., "Supplier selection for steelmaking company by using combined GreyMARCOS methods", Decision Making: Applications in Management and Engineering, 3(2): 37-48, (2020).

[95] Torkayesh, A. E., Zolfani, S. H., Kahvand, M., Khazaelpour, P., "Landfill location selection for healthcare waste of urban areas using hybrid BWM-grey MARCOS model based on GIS”, Sustainable Cities and Society, 67, 102712, (2021).

[96] Chakraborty, S., Chattopadhyay, R., Chakraborty, S., "An integrated D-MARCOS method for supplier selection in an iron and steel industry", Decision Making: Applications in Management and Engineering, 3(2): 49-69, (2020).

[97] Santos, F.J.J., Camargo, H.A., "Fuzzy systems for multicriteria decision making", Clei Electronic Journal, 13(3): 1-9, (2010).

[98] Keshavarz Ghorabaee, M., Zavadskas, E.K., Turskis, Z., Antucheviciene, J., “A new combinative distance-based assessment (CODAS) method for multi-criteria decision-making", Economic Computation \& Economic Cybernetics Studies \& Research, 50(3): 25-44, (2016).

[99] Hwang, C.L., Yoon, K., "Multiple attribute decision-making: Methods and Application", $1^{\text {st }}$ Edition, New York: Springer, 128-141, (1981).

[100] Keshavarz Ghorabaee, M., Zavadskas, E.K., Olfat, L., Turskis, Z., "Multi-criteria inventory classification using a new method of evaluation based on distance from average solution (EDAS)", Informatica, 26(3): 435-451, (2015).

[101] Aytac Adali, E., Tus, A., "Hospital site selection with distance-based multi-criteria decision-making methods", International Journal of Healthcare Management, 14 (2): 534-544, (2021).

[102] Chen, C.T., "Extensions of the TOPSIS for group decision-making under fuzzy environment", Fuzzy Sets and Systems, 114(1): 1-9, (2000).

[103] Keshavarz Ghorabaee, M., Zavadskas, E.K., Amiri, M., Turskis, Z., "Extended EDAS method for fuzzy multi-criteria decision-making: an application to supplier selection", International Journal of Computers Communications \& Control, 11(3): 358-371, (2016).

[104] Keshavarz Ghorabaee, M., Amiri, M., Zavadskas, E.K., Hooshmand, R., Antuchevičienė, J., "Fuzzy extension of the CODAS method for multi-criteria market segment evaluation", Journal of Business Economics and Management, 18(1): 1-19, (2017). 